\title{
Investigating into the Employment and Income Inequality Nexus in Sub-Saharan Africa
}

\section{Suneila Gokhool}

University of Mauritius

Verena Tandrayen Ragoobur ( $\nabla$ v.tandrayen@uom.ac.mu )

University of Mauritius https://orcid.org/0000-0002-8977-754X

Harshana Kasseeah

University of Mauritius

\section{Research}

Keywords: Employment, Income Inequality, Economic Growth and Sub-Saharan Africa

Posted Date: March 30th, 2021

DOI: https://doi.org/10.21203/rs.3.rs-330417/v1

License: (c) (i) This work is licensed under a Creative Commons Attribution 4.0 International License.

Read Full License 


\section{Investigating into the Employment and Income Inequality Nexus in Sub-Saharan Africa}

Authors:

1. Suneila Gokhool

Department of Economics and Statistics

University of Mauritius

Email address: suneila.0511@ gmail.com

2. Dr Verena Tandrayen-Ragoobur

Associate Professor

Department of Economics and Statistics

University of Mauritius

Email address: v.tandrayen@uom.ac.mu

3. Dr Harshana Kasseeah

Associate Professor

Department of Economics and Statistics

University of Mauritius

Email address: $\underline{\text { h.kasseeah@uom.ac.mu }}$

Corresponding Author: $\quad$ Dr Verena Tandrayen-Ragoobur

Associate Professor

Department of Economics and Statistics

University of Mauritius

Email address: v.tandrayen@uom.ac.mu

Word Count: 6572 (excl. references) 


\begin{abstract}
This paper aims to examine the relationship between employment and income inequality in SubSaharan African countries. Even though the region has experienced a decade of positive economic growth, it has the second highest level of income inequality in the world. The drivers of income inequality are quantitatively investigated using data from 1991 to 2015 by the Fully Modified Ordinary Least Squares technique. The results show that employment, trade and domestic investment reduce income inequality in the region in the long term. Higher trade tends to improve income equality in middle-income countries. Alternatively, domestic investment and trade have more potential to reduce inequality in low-income economies. Controlling corruption is essential in the long run for job creation, irrespective of the development stage of the country. There is thus evidence to show that policies must be oriented to more opportunities of employment, domestic investment, trade and good governance in terms of low corruption.
\end{abstract}

Keywords: Employment, Income Inequality, Economic Growth and Sub-Saharan Africa

JEL Codes: J21, N17, O15 


\section{List of Abbreviations}

FMOLS: $\quad$ Fully Modified Ordinary Least Squares

HOS: Heckscher-Ohlin-Samuelson

LAC: $\quad$ Latin America and Caribbean

MENA: $\quad$ Middle East and North Africa.

SSA: $\quad$ Sub-Saharan Africa

SWIID: $\quad$ Standardized World Income Inequality Database

WDI: World Development Indicators

WGI: World Governance Indicators

\section{List of Figures}

Figure 1: Conceptual Framework for Income Inequality

\section{List of Tables}

Table 1: Trends of Gini Coefficient by Regions of the World

Table 2: Distribution of Gini Coefficients for SSA

Table 3: Income Inequality by Income Groups

Table 4: Description of Variables

Table 5: Panel Unit Root Estimation

Table 6: Panel Cointegration Results-Kao Residual Cointegration Test

Table 7: Panel Cointegration Results-Johansen Fisher Panel Cointegration Test

Table 8: FMOLS Results-Employment and Income Inequality Nexus

Table 9: FMOLS Results-Classification of Countries 


\section{Introduction}

Several studies call into question the hopeful "Africa Rising" narrative (Obeng-Odoom, 2015; Nega \& Schneider, 2016). Despite the rapid economic growth over the past decade, Sub-Saharan Africa (SSA) still faces numerous employment and inequality challenges (Benjamin \& Mbaye, 2014; Noman \& Stigitz, 2017; Seguino, 2020). Employment and income equality are two sides of the same coin where employment provides income to satisfy basic necessities, empowers citizens, increases social cohesion, helps to alleviate poverty and reduces the income inequality gap (Lugo, 2007). However, in real life the situation is complex. The proliferation of books on the inequality subject, such as Capital in the $21^{\text {st }}$ Century (Piketty, 2014); Global Inequality: A New Approach for the Age of Globalization (Milanovic, 2016); The Divide: A Brief Guide to Global Inequality and its Solutions (Hickel, 2017); and Political Economy of Inequality (Stilwell, 2019) reflect the prominence of this issue.

Research shows that an excessively equal income distribution can be detrimental for economic efficiency and growth (Singh, 2007). A lack of private profits and differences in wages deprive incentives for workers to actively participate in economic activities. This can further lead to poor quality of goods and services, slow technical progress and slower economic growth with an eventual increase in poverty. On the contrary, excessive income inequality can adversely affect quality of life of individuals in terms of impeding economic progress and human development (Ostry, Berg \& Tsangarides, 2014). 
Given the complexity and severity of the inequality situation in SSA, the nexus of employment and income inequality remain largely unexplained. From both the theoretical and empirical perspectives, employment and income inequality have been mostly studied as two separate strands of the literature. Theories on employment have focused more on the relationship between employment and inflation or economic growth (Phillips, 1958; Al-Zeaud, 2014) while literature on income inequality has paid more attention to its relationship with economic growth and efficiency (Kuznets, 1955; Ostry et al., 2014). Therefore, the main innovation in this paper is to model the relationship of employment and income inequality.

The experience of economies that succeeded in reducing income inequality indicates the importance of both high rates of employment and economic growth in achieving this objective (Islam, 2004). Little attention has been devoted to the role of employment for a more equitable income distribution in SSA. The region has a burgeoning informal sector, where the unstable and vulnerable nature of work contributes to greater inequality (Benjamin \& Mbaye, 2014; ILO, 2016). The region is well known for its high levels of income inequality (Ellis, 2012; Thorbecke, 2013) so much that this topic warrants research attention.

Thus, the main aim of the paper is to investigate into the employment-income inequality nexus. In addition, it explores whether the development level of SSA economies is an important factor in explaining the employment-income inequality relationship. The employment structure is different across nations, for instance, workers in low-income countries are employed in the agricultural sector and receive a fairly homogeneous income. 
Data for SSA economies is compiled from 1991 to 2015 from the World Governance Indicators (WGI) (2017), Solt (2018) and World Development Indicators (WDI) (2018). The methodology adopted in the empirical analysis is a three-step procedure where different diagnostic tests are first carried out to avoid spurious regressions. Second, panel cointegration is used to test for the existence of a long run relationship between employment and income inequality. Lastly, the coefficients are estimated using a Fully Modified Ordinary Least Squares (FMOLS) method. The FMOLS technique accounts for serial correlation and considers endogeneity in the regressors (Kalim \& Shahbaz, 2008; Bashier \& Wahban, 2013).

The rest of this paper is structured as follows: section 2 defines income distribution and its different measures. Section 3 reviews the relevant theoretical and empirical literature on income inequality. Section 4 explores the nature of income inequality in SSA. Section 5 describes the data and methodology used while section 6 analyses the findings. Section 7 concludes.

\section{Income Inequality Definition and Metrics}

Inequality may be measured into different dimensions, including income, assets, capabilities and opportunities (Dabla-Norris et al., 2015). Income inequality is related to poverty and relates to variations in standard of living across the population for a given distribution of income. The basic measure of income inequality is based on the income distribution of individuals. Income distribution can be classified in two ways: the functional and the personal distribution of income. The former shows how much income is received by each factor of production. This concept considers three groups in the economy, namely, labourers, capitalists and landowners and explains 
how income is distributed among labour, capital and land (Bigsten, 1983). The underlying concept of personal distribution of income is how income received from all sources is distributed among individuals or households.

The common measures of income inequality are analysed below.

The Gini coefficient is derived from the Lorenz curve which shows the proportion of income earned by a given percentage of the population. The coefficient lies between 0 and 1 , with 0 representing a perfectly equal nation in which all income is equally shared and 1 reflects a perfectly unequal society where all income is earned by a single individual. The more bowed out the Lorenz curve, the higher is the income inequality in the country. The Gini coefficient, however, cannot be decomposed into inequality within and inequality between groups. From this limitation, the sum of inequality within and between groups will not add up exactly to the overall Gini coefficient. The coefficient is also over-sensitive to changes in the middle of distribution and under-sensitive at the extremes where it does not capture explicitly changes in the top 10 per cent or the bottom 40 per cent in income distribution (Atkinson, 1975).

The variance in the logarithm of income is the decomposable measure of income inequality that can be applied to analyse changes in inequality. One advantage of using the log variance rather than the variance is that it does not change irrespective of the units of measurement for income. The income of the household or individual $i$ is $y_{i}$. If there are $n$ households or individuals in the country, the average of the logarithm of income or log mean $(Y)$ is: 
$Y=\sum_{i=1}^{n} \frac{Y_{i}}{n}$

where $Y_{i}=\ln \left(y_{i}\right)$ and the $\log$ variance $\left(\sigma^{2}\right)$ is given by:

$\sigma^{2}=\sum_{i=1}^{n} \frac{\left(Y_{i}-Y\right)^{2}}{n}$

Another decomposable measure is the Theil index, which explains income inequality at individual household level. The index measures an entropic "distance" the individual is away from the “ideal" egalitarian state of every person having the same income. The result is in terms of negative entropy where a higher number indicates greater equality in the economy. The Theil index is as follows:

$T=\sum_{i=1}^{n} s_{i}\left[\ln \left(s_{i}\right)-\ln (1 / n)\right]$,

where $s_{i}$ is the share of household or individual $i$ in total income.

Atkinson (1975) has found that inequality cannot be measured without introducing social judgements and the Gini coefficient embody judgements about the weight to be attached to inequality at different points on the income scale. The Atkinson index allows for varying sensitivity in different parts of the income distribution. The range of values is 0 to 1 , with 0 being a state of equal distribution. The Atkinson index has a sensitivity parameter $(\varepsilon)$; which ranges from 0 (being indifferent about the nature of income distribution) to infinity (where the concern is with the very 
lowest income group). $\varepsilon$ usually takes values of $0.5,1,1.5$ or 2 . The higher the value of the index, the more sensitive is the Atkinson index to inequalities at the bottom of the income distribution.

The coefficient of variation is another measure of income inequality. It is calculated by dividing the standard deviation of the income distribution by its mean value (Champernowne \& Cowell, 1998). The more equal the income distribution, the smaller standard deviations are. The use of this measure is fairly limited. This may be attributed to the limitations of the coefficient of variation measure, where it does not have an upper bound rendering interpretation and comparison difficult. The mean and standard deviation are also more likely to be influenced by extreme low or high income values, making the measure an inappropriate choice if income does not follow a normal distribution.

Another method of measuring income inequality is the calculation of decile ratios. The decile dispersion ratio presents the ratio of the average consumption of income of the richest 10 per cent of the population divided by the average income of the bottom 10 per cent of the population. The ratio can also be calculated for other percentiles, for instance, the average consumption of the richest 5 per cent is divided by the poorest 5 per cent. This measure enables sensitivity analysis where decile ratios can be compared but it ignores information about incomes in the middle of the income range (World Bank, 2005). 


\section{Literature Review on Determinants of Income Inequality}

\subsection{Theoretical Perspectives}

The modernisation theory explains global inequality within and between countries. Global inequality is the result of differing systems and ideas in the economies. The theory links inequality to different levels of economic development and underlines that some countries are richer than others because of cultural barriers to development (Reyes, 2001; Rostow, 1962). According to this theory, low-income and developing countries in Africa, Asia and Latin America are held back through their traditional values. The theory suggests that low-income countries can move to middle and high-income countries by achieving self-sustained economic growth (Reyes, 2001; Rostow, 1962). The low-income nations can improve their living standards and achieve a more equal distribution of income with economic growth and most importantly the accompanying internal cultural reforms and changes in work attitudes, beliefs and values (Bubaker, 2015; ChanDunn, 2000).

Kuznets (1955) puts forward a theory of distributional change during a country course of development. According to him, in their path of development, countries would necessarily pass through a period of high income inequality derived from the shift from the agricultural sector to the industrial sector and declining inequality was a natural outgrowth of development process. At the start, he assumes that rural agricultural incomes are lower and most inhabitants receive similar returns than urban industrial sector. As an economy continues to develop through the industrialisation process, workers start to move to higher wages in industrial sector, which in turn 
will generate an increase in income inequality. The final phase of this hypothesis, countries reach a certain point of development where the majority of the population is now in industrial activities. Also, at this point, governments will be able to provide general access to education, health programs and income equalising policies. Similarly, the new growth theory claims that investment in knowledge capital may persist indefinitely and can sustain long-run growth in per capita income. With knowledge being treated as a public good, spill-over benefits to other firms may then allow aggregate investment in knowledge to exhibit increasing returns to scale to better the society and eventually inequality declines (Romer, 1994).

The globalisation theory of Heckscher-Ohlin-Samuelson (HOS) can also explain income inequality. In the HOS framework, rewards in real terms of the relatively abundant resources will increase. Countries abundant in resources such as unskilled labour will employ more workers to produce unskilled labour commodities. Demand for lower-skilled labour will therefore rise relative to the skilled ones. But wages are assumed to be flexible with markets in equilibrium and at full employment. An increase in trade will cause inter-sectoral shift towards labour intensive activities with higher wages. The sector specific model assumes that one factor of production is specific to an industry and thereby the net effect for workers depends on their mobility. In immobile factor model, the factor specific to the export industry benefits while the factor specific to the import-competing industry loses. 


\subsection{Employment and Income Inequality}

Several channels of the impact of employment on income inequality can be devised from the literature. This paper has grouped these channels into 2 categories, namely the demand side and supply side, as shown in Figure 1.

\section{- Demand Side - State of the Economy}

The state of the economy is closely associated with three phenomena: globalisation, technical change and new norms of employment (Aghion, Caroli \& García-Peñalosa, 1999; Rama, 2003). The ways in which these factors may affect income inequality are next analysed.

Increasing globalisation has led to a reduction in the number of people living in poverty through increasing efficient use of resources and specialisation in line with a country's comparative advantage (Ricardo, 1817; Kurz and Salvadori, 2003). Thus, regions lagging behind join the economic integration process in order to benefit from it and income inequality between the countries is gradually removed as per the new growth theory (Solow, 1956; Swan, 1956). The hypothesis of Kuznets (1955) declining inequality is a natural outgrowth of development process. The HOS framework emphasises that globalisation benefits the poor and therefore, reduces inequality in poor countries. Countries export goods requiring the relatively abundant and cheap resources and import goods whose production uses intensively the relatively scarce and expensive factor of production (Samuelson, 1948; Vandenberg, 2017). 
Income inequality can be explained by technological change. Implementation of new technologies is usually undertaken by skilled labour only. Skilled workers find employment in the new sectors and earn higher wages. Aghion (2002) explains that unskilled workers remain in old sectors with prevailing wages. Innovation is expected to limit income inequality through the Schumpeterian concept of creative destruction (Schumpeter, 1947; Antonelli \& Gehringer, 2017). Technological change can theoretically lead to both a reduction in wage dispersion where large portions of the existing capital stock lose its value with new innovations. The new norms of employment can also lead to income inequality. Several studies have suggested that neoliberal economic policy such as decentralisation of production, flexibility in labour market and reduction of social welfare have contributed to increasing income inequality (Cornia \& Kiski, 2001; Olsthoorn, 2013). The deregulation and the neoliberal reforms of the labour market have increased the number of unemployed and the share of irregular and vulnerable workers. This situation leads to greater wage inequality in developing countries (Rama, 2003).

\section{- Supply Side - Human Capital}

Kwon (2009) defines human capital as the stock of knowledge and skills which the population of a country has. This knowledge results from economic, social and demographic behaviour, in terms of education, experience, health, training and job search, which impact on the present and future human capital stock (Coremberg, 2010). Investment in human capital implies the sacrifice of present consumption to improve the future income profile. The higher expected income will increase future consumption capacity. Investment in education hence decreases unemployment opportunity cost. There is lower risk of unemployment at higher educational levels since the 
educated workers are more efficient in seeking new job opportunities and gaining higher wages. From the new growth theory, it can be underscored that the production function exhibits increasing returns with investment in human capital and specialisation. Capital investment in both machines and in skills of workers creates positive externalities where investments improve the productive capacity of other related enterprises and labour as well. Spill-over effects of knowledge benefit other firms and workers, allowing increasing returns to scale. Therefore, investment in knowledge capital persists indefinitely and allows a sustained long run growth in income per capita (Solow, 1956). The sustained long term growth eventually leads to a decline in inequality (Romer, 1994).

\section{[Insert Figure 1]}

\subsection{Empirical Studies}

There are various empirical studies examining the determinants of income inequality. The academic literature attributes a change in income inequality mainly to three factors, namely, globalisation, skilled-biased technical changes and economic development. The empirical literature is divided into panel and single country studies.

\section{$\underline{\text { Panel Studies }}$}

Various studies have found a systematic relationship between economic growth and changes in income inequality. Dollar \& Kraay (2002) employ the Generalised Method of Moment to investigate the economic growth and inequality nexus for 92 developing and developed countries 
over four decades. Their findings demonstrate that economic growth is important for poverty reduction. The study of Dollar, Kleineberg \& Kraay (2013) also underscores the importance of economic growth for improving the living standards among the poorest in the economy.

On the contrary, Angeles-Castro (2006) finds a U-shaped curve, where inequality first decreases and then rises with economic growth. Similarly, Lundberg and Squire (2003) use a large sample of 125 countries to conclude that economic growth increases the Gini coefficient. Forbes (2000) also finds a positive relationship between inequality and growth. The author further argues that the reasons for contradiction of results for the economic growth-income equality nexus are data quality, period under consideration, country and omitted variable bias. Many developed economies believed to have reached the peak of income inequality levels find the latter is instead increasing. A 2007 IMF study observes that income inequality in advanced economies is worse than in less developed countries (Lall et al., 2007).

Dubious claims about the welfare impacts of globalisation have been made where no consensus on the effects of trade and financial liberalisation on income distribution have been reached. Meschi and Vivarelli (2007) investigate the distribution consequences of trade flows in 70 countries from 1980 to 1999 . They find that total trade flows are weakly related to income inequality. The authors, further, disaggregate trade flows according to their regions of origin and destination. Findings reveal that both imports and exports with high-income countries worsen income distribution in developing countries. 
Furthermore, Van der Hoeven \& Luebker (2007) show that financial liberalisation increases macroeconomic instability in many developing economies. The instability has negative effects on the income of poor workers and consequently, worsens income inequality. The effects of financial globalisation on income inequality are mixed and inconclusive, according to Cecchetti \& Kharroubi (2012) and Park and Shin (2015). The latter find evidence of a U-shaped relationship between financial development and income inequality for a sample of 162 countries. Equality improves as the financial system develops and reaches the mean level. As the system continues to develop, it leads to a more unequal distribution of income.

Many cross-country studies find supporting evidence for the positive association between trade integration and income inequality in developing countries (Milanovic \& Squire, 2005; McMillan \& Rodrik, 2011). The labour market is a transmission mechanism through which the technical changes of trade induce unemployment and income inequality (McMillan \& Rodrik, 2011). Skillbiased wage differentials worsen demand for low skilled workers (Saba, Dickerson \& Green, 2004). Some studies show that trade liberalisation has equalising effects. For instance, Esquivel (2009) reveals that increased imports from developing countries are associated with lower income inequality, resulting to an increase in low skilled labour-intensive exports such as agricultural goods for developing countries. Jaumotte, Lall \& Papageorgiou (2013) also conclude that trade globalisation is associated with declining inequality using a panel of 51 countries over a 23 -year period.

Change in technology is a more powerful driver of wage inequality than increased trade, according to a study of OECD (2007). Several empirical studies, for example, Esquivel \& Rodriguez-Lopez 
(2003) and McMillan \& Rodrik (2011) find that changing production structures with improvements in communication and information technologies generate skill-biased technical changes. These effects are more pronounced in developing countries than developed ones. Skillbiased technical changes manifest more in developing countries since the presence of productivity gaps between economic sectors tend to be larger (McMillan \& Rodrik, 2011). Jaumotte, Lall \& Papageorgiou (2008) also argue that skill-biased technological progress is a key driver of rising inequality. With information technology, much work has become automated and has favoured workers with analytical skills. High-skilled workers are more demanded at the expense of lowskilled labour.

The literature provides evidence that labour market institutions decrease inequality of the wage distribution (Kierzenknowski \& Koske, 2012). Trade unions have an equalising impact on labour compensation distribution (Betcherman, 2012). Piketty \& Saez (2006) also highlight that changes in unionisation and minimum wages affect low and middle wage workers. Jaumotte \& OsorioBuitron (2015) analyse the relationship between labour market institutions and top income shares in 20 advanced economies. The authors find evidence that the erosion of labour market institutions (for example, financial deregulation, decline in unionisation, lower marginal tax rates for top income earners and erosion of minimum wages) is associated with higher income inequality.

Higher education attainment and an equal distribution of education have a significant role in making income equitable (Gregorio \& Lee, 2002). Rehme (2007) contrasts the role of education. The latter concludes that education has a dual role and simultaneously affects economic growth and income inequality. 


\section{Country-Specific Studies}

Many studies investigating individual countries find that the relationship between globalisation and income inequality is not straightforward. In Poland, wage inequality is reduced in industries where tariffs are decreased (Goh \& Javorcik, 2007). Chen (2016) finds that FDI contributes in reducing urban-rural income inequality in China, with more job creation, spill-over of knowledge and contribution to economic growth. However, empirical findings in India confirm that financial development, economic growth and inflation widen rural-urban income inequality in the long run from 1965 to 2008 (Tiwari, Shahbaz \& Islam, 2013). There is also more demand for skilled whitecollar workers in firms which import capital goods in Mexico (Harrison \& Hanson, 1999).

Lin (2007) investigates how changes in the average level of schooling and educational inequality impact income inequality in Taiwan from 1976 to 2003. His findings suggest higher level of average years of schooling generates lower income inequality. Digdowiseiso (2009) indicates that a higher level of human capital has a disequalising effect on the income distribution for Indonesia from 1996 to 2005. Labour demand from unskilled workers towards skilled workers is most likely to increase income inequality (Lin, 2007). Technical change in China is capital-biased which contributes to reductions in the labour share of income and thus widens the income inequality gap (Zhang et al., 2017).

Explanations advanced for the presence of income inequality have been economic development, globalisation and technological progress. While several countries have been affected by globalisation and changes in technology, income inequality in these economies has been impacted 
by varying speeds. This paper hence examines to what extent income inequality has varied in SSA, a region where empirical studies on the employment-income inequality relationship is limited. Given that globalisation has been biased towards workers in high income countries and increased competition through trade from low wage countries has led to declines in manufacturing sectors in developed economies (Dreher \& Gaston, 2008), this study probes into the employmentincome inequality nexus by considering the level of development within this region.

\section{Data Source and Analysis}

\subsection{Data Source}

Data are obtained from the WDI (2018), Solt (2018) and the WGI (2017) from the period 1991 to 2015.

The Gini indices are used since other measures of income inequality, for example, the Atkinson index and Theil index, are unavailable for SSA. In this paper, income inequality is measured by Solt's post tax/transfer Gini indices from the Standardized World Income Inequality Database (SWIID). Studies such as Bergh \& Nilsson (2010) as well as Herzer \& Nunnenkamp (2015) have

used this dataset. SWIID provides standardised Gini coefficients which maximises comparability for the broadest sample of countries and years (Solt, 2014). Furthermore, it combines information from the World Income Inequality Database, a World Bank database, which offers harmonised micro-data collected from several countries, academic studies and data from the United Nations 
University-World Institute for Development Economics Research, to create a dataset with greater coverage than the World Bank data. SWIID, hence, provides more comparability.

\subsection{A Descriptive Overview of the Income Inequality}

Table 1 provides a global overview of income inequality. It shows income inequality variations over time and among different regions. The figures show that SSA has the second highest level of income inequality in the world with an average Gini coefficient of 47.8, 44.1 and 42.9 for 19912000, 2001-2010 and 2011-2017 respectively, after Latin America and the Caribbean (LAC) for the same time span. Most regions have recorded a period of falling inequality. With rapid growth in Asia, the global distribution of incomes has become less unequal. Extreme inequality is prevalent only in SSA, with the lowest Gini coefficient of 31.5 in Sao Tome and Principe and the highest one in South Africa.

\section{[Insert Table 1]}

Table 2 show the degree of income inequality as measured by the Gini coefficient in SSA with the latest available data. Variation in income is highly visible in many economies. For the 42 countries, the Gini coefficient ranges from the lowest coefficient of 31 in Niger to the highest one of 63 in South Africa. It is important to realise that the aggregate figure of 45.1 from 1991 to 2010 mask differentiated figures at country level, offering a reminder that the region must not be treated as a homogenous block. Table 2 shows that the southern African sub-region has the least egalitarian distribution of income. Six countries in this sub-region: South Africa, Namibia, 
Botswana, Zambia, Lesotho and Swaziland, are among the top ten of the most unequal economies. Ironically, most of these economies are predominantly characterised by oil and mining sectors (Lundgren et al., 2013). Likewise, increases in inequality in SSA are explained by weak economic governance and high dependence on commodity exports (IMF, 2015). Since inequality negatively affects growth and macroeconomic stability in the long run (Ostry et al., 2014), this chapter addresses the role of employment on income inequality in SSA, so far lacking in the empirical literature.

\section{[Insert Table 2]}

In addition, SSA has variable levels of inequality when countries are classified according to income status. Economies are divided into two income groups: low and middle-income ${ }^{1}$. The decline in income inequality is more pronounced in low income groups of countries (Table 3). Even within each income group, there are varying trends. Among the low-income countries, the recent Gini coefficients vary from 31 in Niger to around 51 in Guinea-Bissau and Rwanda. Furthermore, Central African Republic and Comoros have high Gini coefficients of around 56.

\footnotetext{
${ }^{1}$ The World Bank classification of countries by income status is used. The World Bank classifies economies to their respective level of development as measured by the Gross National Income (GNI) per capita, in US\$. Low-income countries are defined as those with a GNI per capita of US\$1,005 or less. Lower middle-income countries have a GNI per capita of more than US\$ 1,006 but less than US\$3,955. Upper middle-income economies have a GNI per capita of more than US\$3,956 but less than US\$12,235. High-income countries are those with a GNI per capita of US\$ 12,235 or more.
}

For this study, economies are divided into two income groups: low-income with 27 countries and middle-income with 20 countries. Seychelles, being a high income country, is not taken on board when the income group analysis is conducted. 
Among the middle-income countries, the Gini coefficients vary from 31 in Sao Tome and Principe to 56 in Zambia.

\section{[Insert Table 3]}

\subsection{Specification of Model}

The empirical approach builds on Dabla-Norris et al. (2015). Since availability of some data is poor, the baseline equation is kept relatively parsimonious. The specification is as follows: $\operatorname{GINI}_{i t}=\beta_{o}+\beta_{1}\left(E M P L_{i t}\right)+\beta_{2}\left(G D P_{i t}\right)+\beta_{3}\left(D I N V_{i t}\right)+\beta_{4}\left(T R A D E_{i t}\right)+\beta_{5}\left(S C H O O L_{i t}\right)+$ $\beta_{6}\left(C C_{i t}\right)+\varepsilon_{t}$,

where $\beta_{0}$ is the constant and $\beta_{1}, \beta_{2}, \beta_{3}, \beta_{4}, \beta_{5}$ and $\beta_{6}$ are the coefficients of the regression equation. The time period and country are denoted by $t$ and $i$ respectively. The variables are explained with their expected relationship in Table 4.

\section{[Insert Table 4]}

\section{$\underline{\text { Independent Variables }}$}

GDP growth is used to capture the economic development of a country. Expected relationship is in line with Forbes (2000) and Lall et al. (2007). Domestic investment is assumed to have a significant role in making income equitable, similar to the findings of Gregorio \& Lee (2002). 
Trade is a proxy for globalisation. Standard trade theory and empirical research have contrasting views on the effect of trade liberalisation on income distribution (Lall et al., 2007; Dreher \& Gaston, 2008).

From theory, it is expected that higher levels of education tend to reduce income inequality since the individuals move out of low-paid jobs into better-paid jobs and educated workers tend to be more economically productive (Psacharopoulo, 1994; Barro, 2000). This is also underscored by empirical studies like Gregorio \& Lee (2002) and Lin (2007). CC is the perception of corruption. It measures the extent to which public power in a country is exercised for private gains (WGI, 2017). It is expected to have a positive relationship with income inequality, as evidenced by Gyimah-Brempong (2002).

\subsection{Hypotheses}

It is first hypothesised that increasing employment levels decrease income inequality. Income created through employment leads to improve standards of living and may decrease income inequality and help in eradicating poverty. For a vast majority of people in SSA, returns to own labour are the most important source of income. Having a job with a stable income to support oneself and the family tends to decrease pay gap (Kierzenknowski \& Koske, 2012). Similarly, Kenworthy (2009) advocates the "high employment route to less inequality" where income inequality has declined in spite of increased non-standard employment. 
The second hypothesis assumes that increasing employment levels reduces income inequality in low-income countries relatively more than in middle-income countries. Low-income economies mainly depend on agriculture. Workers in the agricultural sector receive a fairly homogeneous income according to Kuznets (1955). Hence, more job creation in low-income economies tends to reduce the level of inequality when the majority of the population obtains relatively similar incomes. Alternatively, middle-income nations are more advanced and inequality may rise due to a combination of factors such as globalisation, technological change and change in bargaining power of labour (Aghion et al., 1999; Antonelli \& Gehringer, 2017; Vandenberg, 2017).

\subsection{Methodological Approach}

The first step before estimating the model is to conduct stationarity test. The second step is to run the panel cointegration test for testing the existence of a long run relationship between employment and the independent variables. Thirdly, the coefficients are estimated by the FMOLS method.

\subsubsection{Stationarity Test}

The direct application of Ordinary Least Squares to non-stationary data produces misspecified and spurious regressions (Engle \& Granger, 1987). Similarly, it is necessary for a priori check of unit roots in panel data. The major difference to time series is the consideration to cross-section dimension in panel data. The literature highlights that panel unit root tests are more powerful and are less likely to commit Type II error than unit root tests applied to individual series (Maddala \& Wu, 1999; Im, Pesaran \& Shin, 2003). 
The Levin, Lin \& Chu (LLC) (2002) test is applied to assess the integratedness of the panel data. LLC is a common panel unit root test used in the literature (for example, in Lotfalipour, Montazeri \& Sedighi, 2013; Bidiricia \& Bohur, 2015). It is suitable for macro panels (Levin et al., 2002) but it is limited by the assumption of cross-sectional independence and the null hypothesis also assumes that there is a common unit root, which is very restrictive.

\subsubsection{Panel Cointegration Test}

Panel cointegration test is applied to determine whether there is a stable long-term relationship among the regressors. The Kao and Johansen-Fisher tests are used to verify for this long-term relationship.

\subsubsection{Estimation Method}

Although the methodologies of Kao test and Johansen-Fisher combined individual test allow the testing of the presence of cointegration, they do not provide the estimation of a long run relationship. The FMOLS method (Philips \& Hansen, 1990; Philips 1995) is used to estimate models with full rank I(1) regressors, models with I(1) and I(0) regressors and models with only I(0) regressors. FMOLS is superior to OLS as OLS estimates may suffer from serial correlation and heteroskedasticity. The FMOLS technique accounts for serial correlation and endogeneity issues (Kalim \& Shahbaz, 2008; Bashier \& Wahban, 2013).

The whole group of 48 SSA countries is considered. Country-specific cases are not involved in the estimation because such country-specific effects are eliminated in the FMOLS approach in 
order to avoid endogeneity issues which may be related to the correlation between the dependent variable and country-specific effects.

\section{Results and Discussions}

\subsection{Panel Unit Root Test and Co-integration Results}

Table 5 reports the outcome for the LLC panel unit root tests. The null hypothesis of the unit roots for the panel data for the GINI, EMPL, DINV and SCHOOL series cannot be rejected in level form. This hypothesis is rejected when series are in their first differences. All other variables, namely, GDP, TRADE and CC are stationary at level forms. The model has a combination of both $\mathrm{I}(0)$ and $\mathrm{I}(1)$ variables. Tests for panel cointegration can be conducted, only if there is cointegration between the I(1) variables. Both the Kao and Johansen Fisher tests reject the null hypothesis, implying that a long run relationship exists among the $\mathrm{I}(\mathrm{I})$ variables. Details from the Kao residual cointegration test and the Johansen Fisher panel cointegration test are reported in Table 6 and 7. As long as I(1) variables are cointegrated, including I(0) variables do not change the $\mathrm{I}(0)$ structure of the error term and conventional properties of panel estimation tests.

[Insert Tables 5, 6 and 7]

\subsection{FMOLS Results}

(i). First Hypothesis: Higher employment levels reduce income inequality. 
Table 8 report the long-run empirical estimates. The objective is to investigate whether more job opportunities reduce income inequality in the region. The findings show that employment is indeed a ladder out of income inequality. When EMPL increases by 1 per cent, income inequality is expected to fall by 0.021 units. The result is in conformity with various studies such as Kenworthy (2009) and Kierzenknowski \& Koske (2012).

In comparison, in the pursuing of growth, the gap between the rich and poor widens. Higher GDP leads to more income inequality, consistent with the standard Kuznets theory and empirical studies of Forbes (2000) and Lall et al. (2007).

Considering DINV and TRADE, the evidence shows that domestic investment and trade have a clear inverse relationship with income inequality. These findings are in line with Gregorio \& Lee (2002), Islam (2004) and Jaumotte et al. (2013) which postulate that domestic investment and more trade are essential to decrease inequality. Sub-Saharan Africans are better off if they are provided with more job opportunities, domestic investment increases and the region is more open to trade.

The impacts of education on income inequality are also accounted for. In contrast with the expectations, a higher primary enrolment does not have a significant impact on income inequality. Similar results have been noted by Rehme (2007). On the contrary, the impacts of EMPL, DINV and TRADE are robust with an inverse relationship with income inequality. The estimates show that income inequality is more elastic with respect to domestic investment than employment. A 1 
per cent increase in domestic investment and employment reduces income inequality by 0.059 and 0.026 units respectively.

Next, there is evidence that the higher the perception of corruption in the region, the greater the income inequality gap. In line with the expectations, any forms of corruption, for example, the capture of the state by the elites and public power exercising for private gain, tend to be positively related with income inequality. Gyimah-Brempong (2002) and Apergis, Dincer \& Payne (2010) also confirm this finding.

\section{[Insert Table 8]}

\section{(ii). Second Hypothesis: Higher employment levels reduce income inequality relatively more in low-income countries than in middle-income ones.}

The long-run empirical estimations are reported in Table 9. Considering the socio-economic and political aspect, it can be concluded that employment does not have a significant impact on income

inequality in neither low-income nor high-income countries when education and the perception of corruption are considered. Other variables such as TRADE, DINV and CC have more statistically significant influence on income inequality.

The macroeconomic factors, namely, EMPL, DINV and TRADE do not have statistically significant impact on income inequality in low-income economies. When education is considered, findings show that domestic investment and employment have an income equalising impact in the 
region. With the socio-economic and political approach, findings show that higher domestic investment and more trade reduces income inequality while an increase in corruption causes greater income inequality.

The impact of the macroeconomic factors in middle-income economies is analysed. EMPL and TRADE tend to reduce income inequality. The results are robust when the effects of primary school enrolment are considered. The findings show that income inequality is still more elastic to employment and trade. A higher educated population does not impact much on income inequality. Income inequality worsens with higher level of corruption in the long run. The findings of Table 9 show that trade is more likely to reduce income inequality in middle income countries when the socio-economic and political dimensions are considered.

\section{[Insert Table 9]}

\subsection{Limitations of the Study}

There have been some unavoidable limitations in this study. Firstly, the findings are limited by the variables used. It is also still critical to compile quality annual secondary data for this region even though data has been increasingly available. Much of the data from SSA still suffers from inconsistency in methodology both across and within countries across time (Jerven, 2013). 


\section{Conclusion}

Findings from this paper provide a basis for more employment, domestic investment and trade to decrease income inequality. It can be deduced that more trade for middle-income countries and higher domestic investment in addition to trade reduces inequality in low-income countries.

Countries are unequally endowed with natural, physical capital and human resources and an important question associated with employment is whether the creation of jobs in low incomecountries is likely to reduce income inequality much more than in middle income-economies. The findings obtained indicate that trade is more likely to influence income inequality in middle income-countries when the socio-economic and political dimensions are considered. The results also show that trade and domestic investment may act as a catalyst for other factors to reduce income inequality in low-income countries. Controlling corruption for an equitable distribution of income is essential for both low and middle income countries in the long run.

\section{Appendix}

List of Figures and Tables

\section{References}




\section{Appendix}

Figure 1: Conceptual Framework for Income Inequality

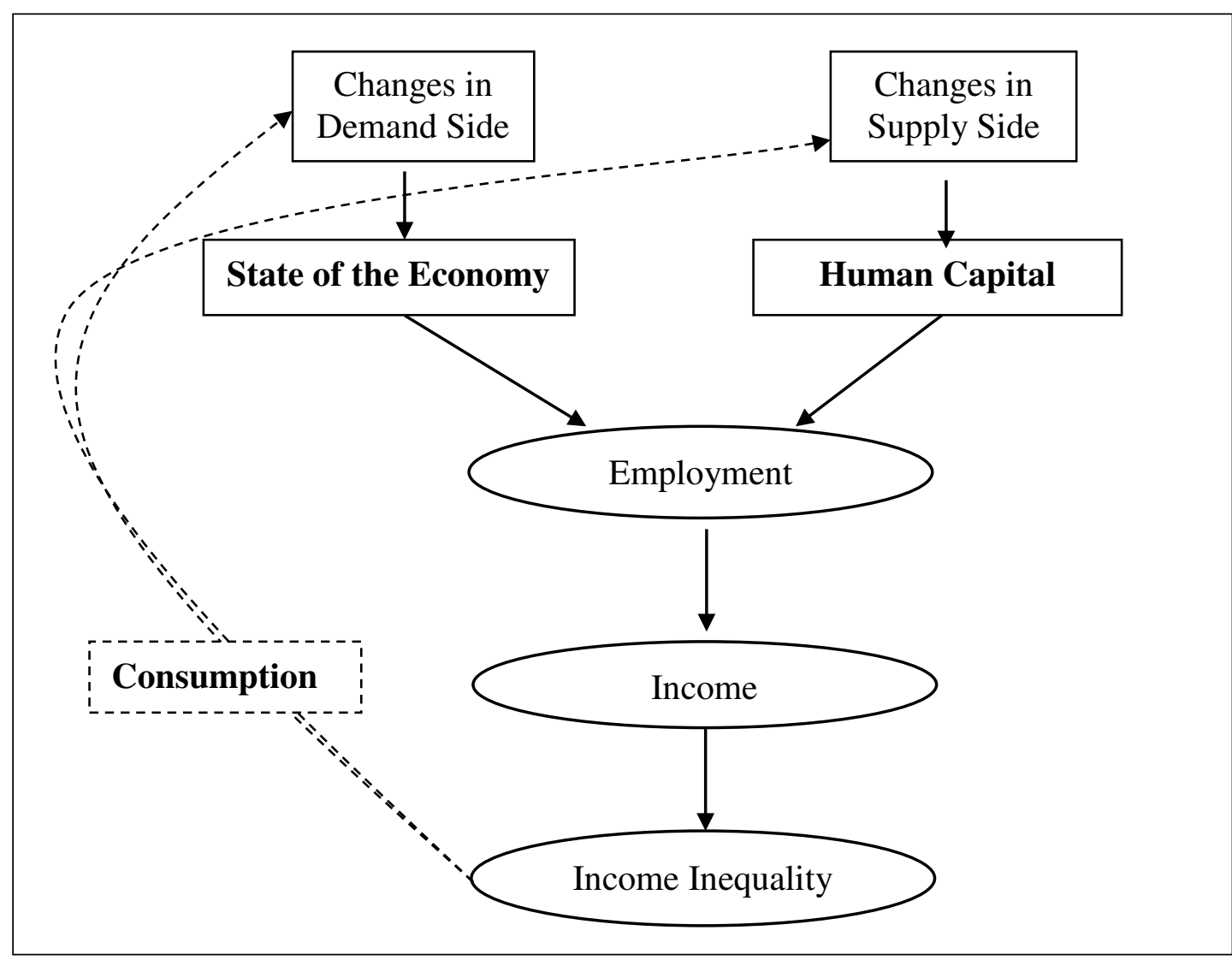

Source: Author's compilation 
Table 1: Trends of Gini Coefficient by Regions of the World

\begin{tabular}{|c|c|c|c|c|c|}
\hline & $\begin{array}{l}1991- \\
2000\end{array}$ & $\begin{array}{l}2001- \\
2010\end{array}$ & $\begin{array}{l}\text { 2011- } \\
2017\end{array}$ & Minimum & Maximum \\
\hline LAC & 51.8 & 50.9 & 46.8 & $\begin{array}{c}40.3 \\
\text { (Trinidad and } \\
\text { Tobago) }\end{array}$ & $\begin{array}{c}57.7 \\
(\text { Belize })\end{array}$ \\
\hline SSA & 47.8 & 44.1 & 42.9 & $\begin{array}{c}31.5 \\
\text { (Sao Tome and } \\
\text { Principe) } \\
\end{array}$ & $\begin{array}{c}61.7 \\
\text { (South Africa) }\end{array}$ \\
\hline $\begin{array}{l}\text { East Asia and } \\
\text { Pacific }\end{array}$ & 39.4 & 38.2 & 37.0 & $\begin{array}{c}30.8 \\
\text { (Timor-Leste) }\end{array}$ & $\begin{array}{c}48.7 \\
\text { (Papua New } \\
\text { Guinea) }\end{array}$ \\
\hline MENA & 37.9 & 37.5 & 34.5 & $\begin{array}{c}30 \\
\text { (Iraq) }\end{array}$ & $\begin{array}{c}45 \\
\text { (Djibouti) }\end{array}$ \\
\hline North America & 36.0 & 37.2 & 37.6 & $\begin{array}{c}32.8 \\
\text { (Canada) }\end{array}$ & $\begin{array}{c}40.5 \\
\text { (United States) }\end{array}$ \\
\hline $\begin{array}{l}\text { Europe and Central } \\
\text { Asia }\end{array}$ & 33.5 & 32.0 & 31.5 & $\begin{array}{c}25.3 \\
\text { (Slovenia) }\end{array}$ & $\begin{array}{c}40.8 \\
\text { (Turkmenistan) } \\
\end{array}$ \\
\hline South Asia & 32.9 & 36.5 & 35.5 & $\begin{array}{c}31.4 \\
\text { (Pakistan) }\end{array}$ & $\begin{array}{c}39.8 \\
\text { (Maldives) }\end{array}$ \\
\hline
\end{tabular}

Source: Solt (2018)

Table 2: Distribution of Gini Coefficients for SSA

\begin{tabular}{|c|l|}
\hline Above 60 & South Africa, Namibia \\
\hline $55-59$ & Central African Republic, Lesotho, Zambia \\
\hline $50-54$ & Botswana, Eswatini, Guinea-Bissau, Mozambique \\
\hline $45-49$ & $\begin{array}{l}\text { Benin, Cabo Verde, Comoros, Congo Rep, Malawi, Senegal, Seychelles, South } \\
\text { Sudan }\end{array}$ \\
\hline $40-44$ & $\begin{array}{l}\text { Angola, Cameroon, Chad, Congo, Dem. Rep, Côte d'Ivoire, Gabon, Ghana, } \\
\text { Kenya, Madagascar, Nigeria, Rwanda, Togo, Uganda, Zimbabwe }\end{array}$ \\
\hline $35-39$ & Burkina Faso, Burundi, Ethiopia, Liberia, Gambia, Mauritius, Sudan, Tanzania \\
\hline $30-34$ & Guinea, Mali, Mauritania, Niger, Sao Tome and Principe, Sierra Leone \\
\hline
\end{tabular}

Source: Author's compilation using Solt (2018)

Table 3: Income Inequality by Income Groups

\begin{tabular}{|l|c|c|c|c|}
\hline & No. of Countries & $\mathbf{1 9 9 1 - 2 0 0 0}$ & $\mathbf{2 0 0 0 - 2 0 1 0}$ & \% Change \\
\hline Low income & 27 & 44.4 & 42.4 & $-4.40 \%$ \\
\hline Middle income & 20 & 48.5 & 48.1 & $-0.85 \%$ \\
\hline
\end{tabular}


Source: Author's compilation using Solt (2016)

Table 4: Description of Variables

\begin{tabular}{|l|l|c|}
\hline Variables & \multicolumn{1}{|c|}{ Description } & $\begin{array}{c}\text { Expected } \\
\text { Relationship }\end{array}$ \\
\hline GINI & Measure of income inequality & Negative \\
\hline EMPL & Total employment, 15+ (in logs) & Positive \\
\hline GDP & Annual percentage growth rate of GDP & Negative \\
\hline DINV & $\begin{array}{l}\text { Gross capital formation (in logs). Data are in constant 2010 } \\
\text { US\$. }\end{array}$ & Negative \\
\hline TRADE & Trade (\% of GDP) & Negative \\
\hline SCHOOL & $\begin{array}{l}\text { Gross primary enrolment ratio, regardless of age, to the } \\
\text { population of the age group }\end{array}$ & Positive \\
\hline CC & Perception of corruption & \\
\hline E & Error term & \multicolumn{1}{|c|}{. } \\
\hline
\end{tabular}

Source: Author's compilation

Table 5: Panel Unit Root Estimation

\begin{tabular}{|l|l|c|c|c|}
\hline & Variables & Level & First differenced & Decision \\
\hline 1 & GINI & $-0.677(0.249)$ & $-6.919(0.000)$ & $\mathrm{I}(1)$ \\
\hline 2 & EMPL & $7.574(1.000)$ & $-5.878(0.000)$ & $\mathrm{I}(1)$ \\
\hline 3 & GDP & $-18.097(0.000)$ & & $\mathrm{I}(0)$ \\
\hline 4 & DINV & $0.214(0.585)$ & $-10.789(0.000)$ & $\mathrm{I}(1)$ \\
\hline 5 & TRADE & $-6.370(0.000)$ & & $\mathrm{I}(0)$ \\
\hline 6 & SCHOOL & $-0.896(0.185)$ & $-10.604(0.000)$ & $\mathrm{I}(1)$ \\
\hline 7 & CC & $-4.382(0.000)$ & & $\mathrm{I}(0)$ \\
\hline
\end{tabular}

Computation from Eviews

Note: Probabilities are within parentheses.

Table 6: Panel Cointegration Results-Kao Residual Cointegration Test

\begin{tabular}{|l|c|c|}
\hline Augmented Dickey- & t-statistics & Prob \\
\cline { 2 - 3 } Fuller & 9.204 & 0.000 \\
\hline
\end{tabular}

Computation from Eviews

Table 7: Panel Cointegration Results-Johansen Fisher Panel Cointegration Test

\begin{tabular}{|c|c|c|c|c|}
\hline $\begin{array}{c}\text { Number of } \\
\text { cointegration equation } \\
\text { (s) }\end{array}$ & $\begin{array}{c}\text { Fisher Statistic } \\
\text { (from trace test) }\end{array}$ & Prob & $\begin{array}{c}\text { Fisher Statistic } \\
\text { (from max-eigen test) }\end{array}$ & Prob \\
\hline None & 257.1 & 0.000 & 176.5 & 0.000 \\
\hline
\end{tabular}




\begin{tabular}{|l|c|l|l|l|}
\hline At most 1 & 131.5 & 0.000 & 94.5 & 0.000 \\
\hline At most 2 & 86.1 & 0.000 & 76.1 & 0.000 \\
\hline At most 3 & 47.8 & 0.006 & 47.8 & 0.006 \\
\hline
\end{tabular}

Computation from Eviews

Table 8: FMOLS Results-Employment and Income Inequality Nexus

\begin{tabular}{|l|c|c|c|}
\hline Variables & \multicolumn{3}{|c|}{ Coefficients } \\
\hline EMPL & $\begin{array}{c}-2.132^{*} \\
(0.746)\end{array}$ & $\begin{array}{c}-2.616^{*} \\
(1.064)\end{array}$ & $\begin{array}{c}-2.842^{*} \\
(1.497)\end{array}$ \\
\hline GDP & $\begin{array}{l}0.044^{* *} \\
(0.020)\end{array}$ & $\begin{array}{c}0.007 \\
(0.030)\end{array}$ & $\begin{array}{c}0.006 \\
(0.030)\end{array}$ \\
\hline DINV & $-3.723^{*}$ & $-5.863^{*}$ & $-3.786^{*}$ \\
& $(2.319)$ & $(2.187)$ & $(1.701)$ \\
\hline TRADE & $-0.018^{*}$ & $-0.039^{*}$ & $-0.039^{*}$ \\
\hline SCHOOL & $(0.006)$ & $(0.011)$ & $(0.012)$ \\
\hline CC & & 0.006 & -0.015 \\
& & $(0.011)$ & $(0.016)$ \\
\hline Adj R-squared & & & $1.673^{*}$ \\
\hline
\end{tabular}

Note: Asterisks $(*),(* *)$ and $(* * *)$ denote significance level at $1 \%, 5 \%$ and $10 \%$.

Standard errors are in parentheses.

Computation from Eviews

Table 9: FMOLS Results-Classification of Countries

\begin{tabular}{|l|c|c|c|c|c|c|}
\hline & \multicolumn{3}{|c|}{ Low-Income } & \multicolumn{3}{c|}{ Middle-Income } \\
\hline Variables & \multicolumn{3}{|c|}{ Coefficients } & \multicolumn{3}{c|}{ Coefficients } \\
\hline \multirow{2}{*}{ EMPL } & 1.331 & $-1.055^{*}$ & -2.621 & $-1.780^{* *}$ & $-2.757^{* *}$ & -0.237 \\
& $(1.231)$ & $(2.991)$ & $(2.820)$ & $(0.868)$ & $(1.114)$ & $(2.340)$ \\
\hline
\end{tabular}




\begin{tabular}{|l|c|c|c|c|c|c|}
\hline GDP & $\begin{array}{c}0.075^{* *} \\
(0.029)\end{array}$ & $\begin{array}{c}0.095 \\
(0.066)\end{array}$ & $\begin{array}{c}0.026 \\
(0.066)\end{array}$ & $\begin{array}{c}-0.028 \\
(0.007)\end{array}$ & $\begin{array}{c}-0.032 \\
(0.024)\end{array}$ & $\begin{array}{c}0.015 \\
(0.028)\end{array}$ \\
\hline DINV & $\begin{array}{c}-3.178 \\
(1.701)\end{array}$ & $\begin{array}{c}-5.648^{* *} \\
(2.854)\end{array}$ & $\begin{array}{c}-3.632^{* * *} \\
(2.042)\end{array}$ & $\begin{array}{c}-9.300 \\
(6.395)\end{array}$ & $\begin{array}{c}-4.306 \\
(2.187)\end{array}$ & $\begin{array}{c}-22.405 \\
(15.880)\end{array}$ \\
\hline TRADE & -0.010 & $\begin{array}{c}-0.037 \\
(0.028)\end{array}$ & $\begin{array}{c}-0.054 * * \\
(0.026)\end{array}$ & $\begin{array}{c}-0.040^{*} \\
(0.007)\end{array}$ & $\begin{array}{c}-0.044 * \\
(0.007)\end{array}$ & $\begin{array}{c}-0.029 * \\
(0.011)\end{array}$ \\
\hline SCHOOL & & $\begin{array}{c}-0.008 \\
(0.025)\end{array}$ & $\begin{array}{c}0.021 \\
(0.027)\end{array}$ & & $\begin{array}{c}0.014 \\
(0.015)\end{array}$ & $\begin{array}{c}-0.019 \\
(0.041)\end{array}$ \\
\hline CC & 183 & 158 & 71 & 183 & 133 & $\begin{array}{c}2.265 * * \\
(1.048)\end{array}$ \\
\hline Adj R-squared & 0.992 & 0.992 & 0.970 & 0.829 & 0.773 & 0.934 \\
\hline Observations & $184 *$ & & & & \\
\hline
\end{tabular}

Note: Asterisks $(*),(* *)$ and $(* * *)$ denote significant level at $1 \%, 5 \%$ and $10 \%$.

Standard errors are in parentheses.

Computation from Eviews 


\section{Declarations}

Availability of data and materials - Data can be made available to the Editor whenever required.

Competing interests - No Competing Interests

Funding - No funding obtained for this paper.

Authors' contributions - Confirm all authors' contribution to the paper. All authors have been

included.

Acknowledgements - None

Authors' information (optional)

\section{Authors:}

\section{Suneila Gokhool}

Department of Economics and Statistics

University of Mauritius

Email address: suneila.0511@gmail.com

2. Dr Verena Tandrayen-Ragoobur

Associate Professor

Department of Economics and Statistics

University of Mauritius

Email address: v.tandrayen@uom.ac.mu

3. Dr Harshana Kasseeah

Associate Professor

Department of Economics and Statistics

University of Mauritius

Email address: $\underline{\text { h.kasseeah@uom.ac.mu }}$

Corresponding Author: $\quad$ Dr Verena Tandrayen-Ragoobur

Associate Professor

Department of Economics and Statistics

University of Mauritius Email address: v.tandrayen@uom.ac.mu 
Aghion P (2002) Schumpeterian growth theory and the dynamics of income inequality. Econometrica, 70(3), pp 855-882.

Aghion P, Caroli E, García-Peñalosa C (1999) Inequality and Economic Growth: The Perspective of the New Growth Theories. Journal of Economic Literature, 37(4), 1615-1660. doi:10.1257/jel.37.4.1615

Al-Zeaud HA (2014) The trade-off between unemployment and inflation evidence from causality test for Jordan. International Journal of Humanities and Social Science, 4(4), pp. 103-111.

Angeles-Castro G (2006) The relationship between economic growth and inequality: evidence from the age of market liberalism. University of Kent. Working Paper.

Antonelli C, Gehringer A (2017) Technological change, rent and income inequalities: A Schumpeterian approach. Technological Forecasting and Social Change, 115, 85-98. doi: 10.1016/j.techfore.2016.09.023. Atkinson AB (1975) The economics of inequality. Oxford: Clarendon Press.

Bashier AAA, Wahban AN (2013) The determinants of employment in Jordan: A time series analysis. International Review of Management and Business Research, 2(4), pp 927.

Barro RJ (2000) Education and economic growth. Mimeo, Harvard University.

Benjamin N, Mbaye AA (2014) Informality, Growth, and Development in Africa. Working Paper 2014/052. Helsinki: UNU-WIDER.

Bergh A and Nilsson T (2010) Do liberalization and globalization increase income inequality? European Journal of political economy. 26(4), pp 488-505.

Betcherman G (2012) Labor market institutions: A review of the literature. World Bank Policy Research Working Paper, (6276).

Bidirici M, Bohur E (2015) Design and Economic Growth: Panel Cointegration and Causality Analysis. Procedia-Social and Behavioral Sciences, 210, pp.193-202.

Bigsten A (1983). Income distribution and development; theory, evidence, and policy. Heinemann, London. Brubaker R (2015) Difference and inequality. Grounds for Difference, pp 10-47.

Cecchetti SG, Kharroubi E (2012) Reassessing the Impact of Finance on Growth. BIS Working Papers. No. 381. Frankfurt: Bank for International Settlements.

Champernowne DG, Cowell FA (1998) Economic inequality and income distribution. Cambridge: Cambridge University Press.

Chen C (2016) The impact of foreign direct investment on urban-rural income inequality: Evidence from China. China Agricultural Economic Review. 8(3), pp. 480-497.

Coremberg A (2010) The economic value of human capital and education in an unstable economy: The case of Argentina. In International Association for Research in Income and Wealth, Thirty-first General Conference-St. Gallen, Switzerland, August. pp 22-28. 
Cornia GA, Kiski A (2001) Trends in income distribution in the post-world war II period: Evidence and interpretation. UN-WIDER Discussion paper No. 2001/89.

Dabla-Norris ME, Kochhar MK, Suphaphiphat MN, Ricka MF, Tsounta E (2015) Causes and consequences of income inequality: a global perspective. IMF.

Deininger K, Squire L (1996) A New Data Set Measuring Income Inequality. World Bank.

Digdowiseiso, K (2009) Education inequality, economic growth, and income inequality: Evidence from Indonesia, 1996-2005. Department of Economics, University of National, Indonesia

Dollar D, Kraay A (2002) Growth is good for the Poor. Journal of economic growth, 7(3), pp 195-225.

Dollar D, Kleineberg T, Kraay A (2016) Growth still is good for the poor. European Economic Review, 81, pp 68-85.

Dreher A, Gaston N (2008) Has globalization increased inequality? Review of International Economics, 16(3), pp 516-536.

Ellis F (2012) We Are All Poor Here: economic difference, social divisiveness and targeting cash transfers in Sub-Saharan Africa. Journal of Development Studies, 48(2), pp 201-214.

Engle RF, Granger CWJ (1987) Cointegration and Error Correction: Representation, Estimation, and Testing. Econometrica, Vol. 55, 1987, pp 251-76.

Esquivel G (2009) The Dynamics of Income Inequality in Mexico since NAFTA. Research for Public Policy, Inclusive Development, ID-02-2009, RBLAC-UNDP, New York.

Esquivel G, Rodriguez-López JA (2003) Technology, trade, and wage inequality in Mexico before and after NAFTA. Journal of Development Economics, 72(2), pp 543-565.

Forbes KJ (2000) A reassessment of the relationship between inequality and growth. American economic review, pp 869-887.

Gregorio DJ, Lee J (2002) Education and Income Inequality: New Evidence from Cross country Data. The Review of Income and Wealth 48, pp 395-416.

Gyimah-Brempong K (2002) Corruption, economic growth, and income inequality in Africa. Economics of Governance, 3(3)., pp183-209.

Harrison A, Hanson G (1999) Trade and Wage Inequality in Mexico. Industrial and Labor Relations Review, 52(2).

Herzer D, Nunnenkamp P (2015) Income inequality and health: Evidence from developed and developing countries. Economics, 9(4).

Hickel J (2017) The Divide: A Brief Guide to Global Inequality and its Solutions. London: Penguin Random House UK.

ILO (2016) World Employment and Social Outlook: Trends 2016. Geneva: ILO. 
Im KS, Pesaran MH, Shin Y (2003) Testing for Unit Roots in heterogeneous Panels. Journal of Economics. 115:53-74.

IMF (2015) Regional Economic Outlook: Sub-Saharan Africa. Inequality and Economic Outcomes in SubSaharan Africa.

Islam R (2004) The nexus of economic growth, employment and poverty reduction: An empirical analysis. Recovery and Reconstruction Department. ILO.

Jaumotte F, Osorio-Buitron C (2015) Inequality and labor market institutions. SSRN 2678639.

Jaumotte F, Lall S, Papageorgiou C (2008) Rising income inequality: technology, or trade and financial globalization? IMF Working Paper, WP/08/185.

Jaumotte F, Lall S, Papageorgiou, C (2013) Rising income inequality: technology, or trade and financial globalization? IMF Economic Review, 61(2), pp 271-309.

Jerven M (2013) Poor numbers: how we are misled by African development statistics and what to do about it. Cornell University Press.

Kalim, R, Shahbaz M (2008) Remittances and poverty nexus: Evidence from Pakistan. International Research Journal of Finance and Economics, 29, pp 46-59.

Kenworthy L (2009) The High-Employment Route to Low Inequality. Challenge, 52(5), pp 77-99.

Kierzenkowski R, Koske I (2012) Less income inequality and more growth-are they compatible? Part 8. The drivers of labour income inequality-a literature review.

Kurz HD, Salvadori, N (2003) Theories of economic growth: old and new. The Theory of Economic Growth: A 'Classical' Perspective, Cheltenham: Edward Elgar, pp 1-22.

Kuznets S (1955) Economic growth and income inequality. The American Economic Review, 45(1), 1-28.

Kwon DB (2009) Human capital and its measurement. In the $3^{\text {rd }}$ OECD World Forum on "Statistics, Knowledge and Policy" Charting Progress, Building Visions, Improving Life, pp 27-30.

Lall S, Jaumotte F, Papageorgiou C, Topalova P (2007) Globalization and Inequality. World Economic Outlook, pp 135-169.

Levin A, Lin CF, Chu C (2002) Unit Root Tests in Panel Data: Asymptotic and Finite-Sample Properties. Journal of Econometrics. Vol. 108, 2002, pp 1-24.

Lin CH (2007) Education Expansion, Education Inequality, and Income Inequality: Evidence from Taiwan 1976-2003. Social Indicators Research, 80: 601-615.

Lotfalipour MR, Montazeri S, Sedighi, S (2013) Trade Openness and Inflation. Evidence from MENA Region Countries. Economic Insights-Trends and Challenges, 2.

Lugo AM (2007) Employment: A Proposal for internationally comparable indicators. Oxford Development Studies, 35(4), pp 361-378. 
Lundberg M, Squire L (2003) The simultaneous evolution of growth and inequality. The Economic Journal, 113(487), pp 326-344.

Lundgren CJ, Thomas MAH, York MRC (2013) Boom, Bust or Prosperity? Managing Sub-Saharan Africa's Natural Resource Wealth. International Monetary Fund.

Maddala GS, Wu S (1999) A Comparative Study of Unit Root Tests with Panel Data and A New Simple Test. Oxford Bulletin of Economics and Statistics, 61, pp 631-652.

McMillan MS, Rodrik D (2011) Globalization, structural change and productivity growth. No. w17143. National Bureau of Economic Research.

Meschi E, Vivarelli M (2007) Trade openness and income inequality in developing countries. Working Paper. Coventry: University of Warwick. Centre for the Study of Globalisation and Regionalisation.

Milanovic B (2016) Global Inequality: A New Approach for the Age of Globalization. Harvard University Press. Cambridge.

Milanovic B, Squire L (2005) Does tariff liberalization increase wage inequality? Some empirical evidence. No. w11046. National Bureau of Economic Research.

Nega B, Schneider G (2016) Africa rising? Short-term growth vs. deep institutional concerns. In Forum for Social Economics. Vol. 45, No. 4, pp 283-308. Routledge.

Noman A, Stiglitz J (2015) Industrial Policy and Economic Transformation in Africa. Columbia University Press.

Obeng-Odoom F (2015) Africa: On the Rise, but to Where? Forum for Social Economics, 44:3, pp 234250.

OECD (2007) Offshoring and Employment: Trends and Impacts. OECD Publishing, Paris.

Olsthoorn M (2013) Measuring precarious employment: a proposal for two indicators of precarious employment based on set-theory and tested with Dutch labour market data. Social Indicators Research, 119(1), pp 421 - 441.

Ostry JD, Berg A, Tsangarides C (2014) Redistribution, Inequality, and Growth. IMF Staff Discussion Note 14/02. International Monetary Fund, Washington.

Park D, Shin K (2015) Economic Growth, Financial Development, and Income Inequality. Asian Development Bank Economics Working Paper Series, (441).

Phillips AW (1958) The relation between unemployment and the rate of change of money wage rates in the United Kingdom, 1861-1957. Economica, 25(100), pp 283-299.

Phillips PC (1995) Fully modified least squares and vector autoregression. Econometrica: Journal of the Econometric Society, pp 1023-1078.

Phillips P, Hansen B (1990) Statistical Inference in Instrumental Variables Regression with I(1) Processes. Review of Economic Studies, 57, pp 99-125. 
Piketty T, Saez E (2006) The evolution of top incomes: a historical and international perspective. No. w11955. National Bureau of Economic Research.

Piketty T (2014) Capital in the Twenty-First Century. Cambridge, London: The Belknap Press of Harvard University Press.

Psacharopoulos G (1994) Returns to investment in education: A global update. World development, 22(9), pp1325-1343.

Rama M (2003) Globalization and workers in developing countries. World Bank Policy Research, Working Paper 2958.

Rehme G (2007) Education, Economic Growth, and Measured Income Inequality. Economica, 74: pp 493514.

Reyes GE (2001) Theory of globalization: Fundamental basis. Sincronia Spring, pp 1-5.

Ricardo D (1817) On the principles of political economy and taxation. Batoche Books. Kitchener: Canada. Romer PM. (1994) The origins of endogenous growth. The Journal of Economic Perspectives, 8(1), 3-22.

Rostow WW (1962) The process of economic growth Oxford, Clarendon Press.

Saba AJ, Dickerson A, Green F (2004) Trade Liberalization and Wages in Developing Countries. Economic Journal, 114(493), pp 73-96.

Samuelson PA (1948) International Trade and the Equalization of Factor Prices. Economic Journal 58 (230): pp 163-84.

Schumpeter JA (1947) The Creative Response in Economic History. The Journal of Economic History, 7(2), pp 149-159.

Schwarzer J (2016) Trade and Employment: An Overview. Edited by Leonor von Limburg. Deutsche Gesellschaftfür Internationale Zusammenarbeit GmbH: Germany.

Seguino S (2020) Inequality and Economic Stratification: Reflections on Bromley, Piketty,and ObengOdoom. Forum for Social Economics. Routledge, pp 1-9.

Singh K (2007) Quantitative social research methods. Sage.

Solow R (1956) A Contribution to the Theory of Economic Growth. The Quarterly Journal of Economics. Vol. 70 .

Solt F (2014) The Standardized World Income Inequality Database. Social Science Quarterly

Solt F (2018) The standardized world income inequality database. Social Science Quarterly.

Stilwell F (2019) The Political Economy of Inequality. Polity, Cambridge.

Swan TW (1956) Economic Growth and Capital Accumulation. Economic Record, 32, pp 334-61.

Thorbecke E (2013) The interrelationship linking growth, inequality and poverty in Sub Saharan Africa. Journal of African Economies, 22 (suppl 1), i15-i48. 
Tiwari AK, Shahbaz M, Islam F (2013) Does financial development increase rural-urban income inequality? Cointegration analysis in the case of Indian economy. International Journal of Social Economics, 40(2), pp 151-168.

Van Der Hoeven R, Luebker M (2007) Financial Openness and Employment: The Need for Coherent International and National Policies. Chapter 2 In Occampo, JA and Jomo, KS, 2007, Towards full and Decent Employment, London, Zed Books.

Vandenberg P (2017) Can trade help achieve the employment targets of the sustainable development goals? (No. 650). ADBI working paper series.

WDI (2017) Data - World Development Indicators. World Bank.

WDI (2018) Data - World Development Indicators. World Bank.

WGI (2017) Data - Worldwide Governance Indicators. World Bank.

World Bank (2005) Chapter 6 Inequality Measures. Poverty Manual, All, JH Revision. pp 95-105.

Zhang X, Wan G, Wang C, Luo, Z (2017) Technical change and income inequality in China. The World Economy, 40(11), pp 2378-2402. 
Figures

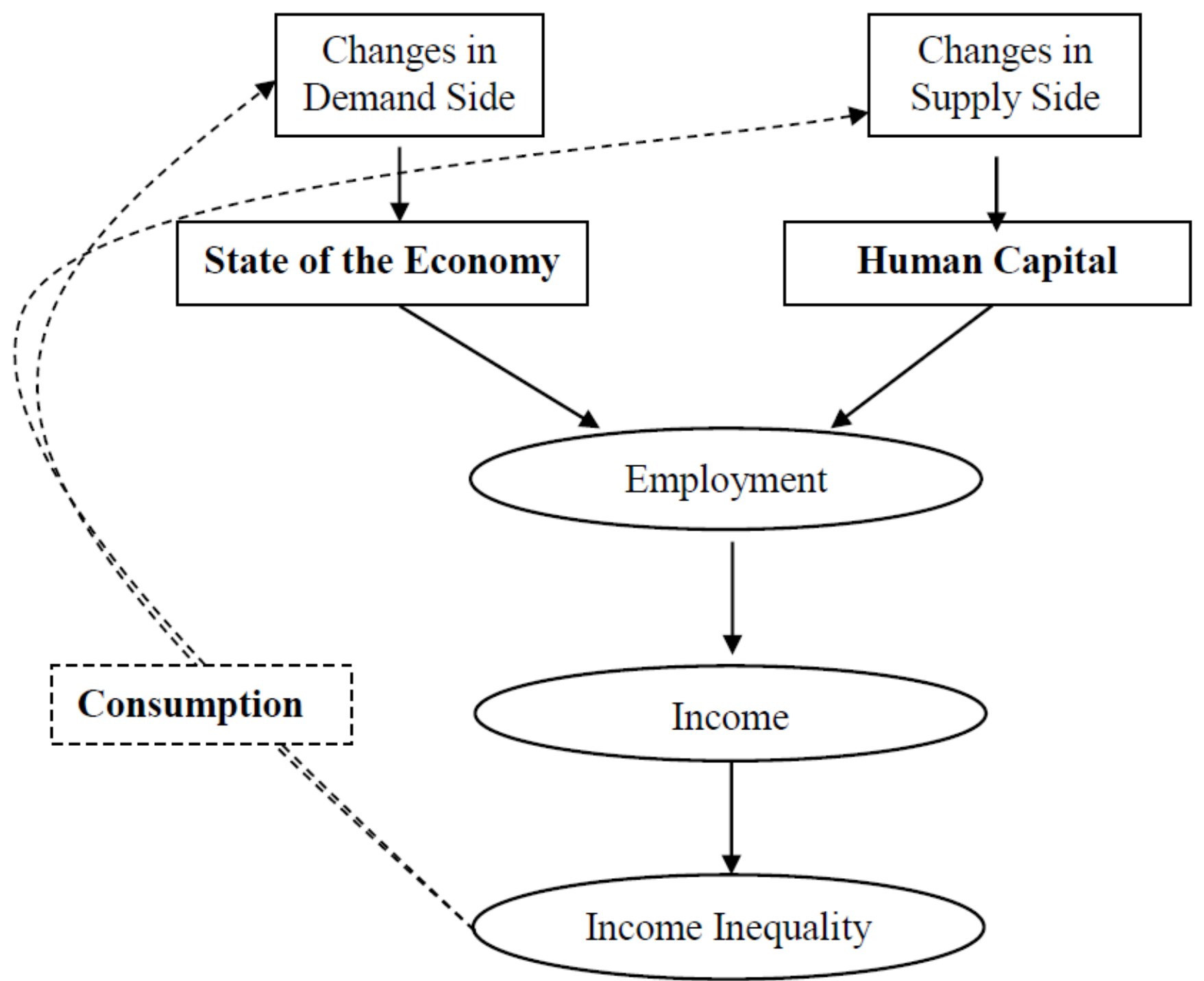

Figure 1

Conceptual Framework for Income Inequality. Source: Author's compilation 